\title{
MOTERŲ PSICHOMOTORINĖS REAKCIJOS GREIČIO PRIKLAUSOMUMAS NUO MENSTRUACINIO CIKLO FAZIŲ
}

\author{
Laura Daniusevičiūtè ${ }^{1,2}$, Albertas Skurvydas ${ }^{1}$, Irina Ramanauskiené $\dot{2}^{2}$, Vitas Linonis ${ }^{2}$, \\ Saulè Sipavičiené ${ }^{1}$, Marius Brazaitis ${ }^{1}$ \\ Lietuvos kūno kultūros akademija ${ }^{1}$, Kauno technologijos universitetas ${ }^{2}$, Kaunas, Lietuva
}

Laura Daniusevičiūtė. Lietuvos kūno kultūros akademijos biomedicinos mokslų krypties doktorantė. Kauno technologijos universiteto Kūno kultūros ir sporto centro, Kūno kultūros katedros metodininkè. Mokslinių tyrimų kryptis — motorinès sistemos nuovargio priklausomumas nuo moteru menstruacinio ciklo fazès.

\section{SANTRAUKA}

Tyrimo tikslas - nustatyti moteru psichomotoriness reakcijos greičio priklausomuma nuo menstruacinio ciklo faziu: folikulines ir ovuliacijos.

Tiriamosios — sveikos nesportuojančios, turinčios natūralu mènesiniu cikla, fiziškai aktyvios merginos $(n=9)$, kuriu amžius - 19-23 metai, kūno mase - 58,2 $\pm 6,1 \mathrm{~kg}$, ügis - 168,4 $\pm 5,6 \mathrm{~cm}$. Visos tiriamosios nevartojo hormoniniu preparatu ne mažiau kaip 6 mènesius ir turèjo reguliaru menstruacinị cikla. Kiekvieno eksperimento pradžioje buvo paimamas $5 \mathrm{ml}$ veninio kraujo méginys menstruacinio ciklo fazèms (folikulinei ir ovuliacinei) nustatyti. Tyrimo metu estradiolio koncentracija kraujyje nustatyta 2 dienq nuo menstruacinio ciklo pradžios (folikulinèje fazèje) ir 14 diena nuo menstruacinio ciklo pradžios (ovuliacijos metu) (Vaičeliünienè ir kt., 2006). Kiekviena tiriamoji 7 valanda ryte 3 mènesius prieš eksperimenta matavo rektalinę temperatūrq — šitaip nustatyta mènesiniu ciklo trukmè, reguliarumas. Psichomotorinès reakcijos laikas (RL) buvo matuojamas reakciometru (RA-1, „,Baltec CNC Technologies “, Lietuva), skirtu psichomotorinès reakcijos greičiui ir centrinès nervu sistemos funkcinei büklei vertinti. Savaitę prieš eksperimenta kiekviena tiriamoji atskirai buvo mokoma atlikti psichomotorinès reakcijos laiko testa. Tiriamosios buvo mokomos vienq kartq atlikti po 15 bandymu abiem rankom. Eksperimento metu prieš krūvi ir po jo registruotas kairès ir dešinès rankos reakcijos laikas (nuo lemputès užsidegimo iki klavišo paspaudimo momento (ms)). Tiriamosios atliko 15 bandymu abiem rankom. Su kiekviena tiriamaja atlikti 2 eksperimentai: folikulinèje fazèje ir ovuliacijos metu. Eksperimentu dienas paskirdavo tyrèjas, atsižvelgdamas i kiekvienos tiriamosios ménesiniu ciklo trukmę ir ovuliacijos dienq. Tiriamosios po 10 -15 min neintensyvios pramankštos (lèto važiavimo velorgometru, kai pulso dažnis 120 $130 \mathrm{k}$. / min) ant kontaktines platformos nuo $75 \mathrm{~cm}$ aukščio pakylos atliko 100 šuoliu, amortizuojamai pritūpdamos per keliu sqnarius iki $90^{\circ}$ kampo (rankos ant juosmens). Laiko intervalas tarp visu šuoliu - 20 sekundžiu.

Išanalizavus gautus duomenis galima teigti, kad reakcija i paprasta dirgiklí buvo ilgesnè ovuliacijos metu nei folikulinejje fazèje, tačiau šis skirtumas nebuvo statistiškai reikšmingas. Reakcijos i paprasta dirgiklį ir estradiolio koncentracijos kraujyje koreliaciniai vertinimai rodè silpna koreliacinị ryš̨ tiek ovuliacijos metu, tiek folikulinèje fazèje.

Raktažodžiai: psichomotorinès reakcijos laikas, folikulinè fazè, ovuliacija.

\section{IVADAS}

K iekviena moteris nuo menarchès iki menopauzès kas mėnesi patiria fiziologinius ir neurocheminius pokyčius. Moksliniais tyrimais patvirtinta, kad šie cikliniai svyravimai veikia moterų nuotaiką, bendrą savijautą, taip pat gyvenimo kokybę, neabejojama ir jų svarba kasdieniame moters gyvenime (Nelson, 2006). Moters lytinių ląstelių ciklą valdo centrinè nervų sistema
(CNS), lytiniai steroidiniai hormonai veikia CNS funkcionavimą. Šie hormonų koncentracijos kraujyje svyravimai sumažina organizmo motorinę koordinaciją, atsiranda bendras organizmo nuovargis, raumenų sustingimas, galvos skausmai ir daugelis kitų simptomų (Farage et al., 2008).

Moters lytinio hormono progesterono receptoriai, esantys smegenų žievejje, pagumburyje ir 
limbinèse srityse, veikia kognityvines funkcijas. Kai kurie progesterono metabolitai gali padidinti nerimastingumą (Wolkowitz, Rothschild, 2003). Atsparumą neigiamoms emocijoms mažina hormono progesterono koncentracijos išaugimas prieš prasidedant ménesinėms (Morofushi et al., 2001). Kraujyje esant estrogeno koncentracijos sutrikimams, gali pasireikšti Parkinsono ligos simptomai, žmogaus judesiai gali pasidaryti nerangūs (McEwen, Alves, 1999). Menopauzès metu, kai pakinta moters hormonu veikla (kiaušidès nustoja gaminusios estrogenus), keičiasi moteru atmintis, mąstymas, reakcijos laikas, elgesys (Farage et al., 2008). Mokslininkai S. M. Philips ir B. B. Sherwin (1992), tyrinèdami dèmesio sukaupimą, vizualinę atminti, nustate, kad šios savybès pagerejja liuteininèje fazèje, kai progesterono koncentracija kraujyje yra padidejusi. Taip pat mokslininkai, tyrinėdami motorinę koordinacija, koordinacijos greiti, motorinį aktyvumą nustatè, kad šios organizmo funkcijos yra geresnès liuteininèje nei folikulinèje menstruacinio ciklo fazeje, kai estrogeno koncentracija kraujyje nėra didžiausia (Maki et al., 2002; Farage et al., 2008). Visgi kaip estrogenas, kai jo koncentracija kraujyje yra didžiausia (ovuliacijos metu), veikia šias organizmo funkcijas? Juk kai estrogeno koncentracija kraujyje yra didžiausia, pagumburis išskiria dideli GnRH (pagumburio hormonas, kuris skatina hipofizès priekinę dali išskirti folikulą stimuliuojanti hormoną (FSH) ir liuteinizuojanti hormoną (LH)) kieki (Farage et al., 2008). Neaiš$\mathrm{ku}$, kaip suaktyvejus organizmo neurocheminiams procesams, bus paveiktas reakcijos laikas, ar šis estrogeno koncentracijos padidejjimas paveiks ji. Taigi tyrimo tikslas - nustatyti moteru psichomotorinès reakcijos greičio priklausomumą nuo menstruacinio ciklo fazių: folikulinès ir ovuliacijos.

\section{TYRIMO METODIKA}

Tiriamosios - sveikos nesportuojančios, turinčios natūralų mėnesinių ciklą, fiziškai aktyvios merginos $(\mathrm{n}=9)$, kurių amžius - 19-23 m., kūno masè $-58,2 \pm 6,1 \mathrm{~kg}$, ūgis $-168,4 \pm 5,6 \mathrm{~cm}$. Visos tiriamosios nevartojo hormoniniu preparatų ne mažiau kaip 6 mènesius ir turejo reguliaru menstruacini ciklą. Kiekviena tiriamoji 7 valanda ryte 3 menesius prieš eksperimenta matavo rektalinę temperatūra - šitaip nustatyta mènesiniu ciklo trukmè, reguliarumas. Merginos atrinktos atsitiktinès atrankos metodu. Tyrimo protokolas aptartas ir patvirtintas Kauno regioniniame biomediciniu tyrimu etikos komitete (protokolo Nr. BE-2-24).
Moterišku lytinių hormonu koncentracijos nustatymas. Lietuvos kūno kultūros akademijos Žmogaus motorikos laboratorijoje bendrosios praktikos slaugytoja kiekvieno eksperimento pradžioje paimdavo $5 \mathrm{ml}$ veninio kraujo mėgini. Kraujo mėginys iškart po paèmimo mègintuvėlyje gabenamas i specializuotą laboratoriją, kur imunofermentiniu metodu buvo nustatoma estradiolio (17ß-estradiolis) koncentracija kraujyje. Šis tyrimas patvirtindavo organizmo menstruacinio ciklo fazes: folikulinę ir ovuliacinę.

Psichomotorinès reakcijos laiko testavimas. Lietuvos kūno kultūros akademijos Žmogaus motorikos laboratorijoje tiriamosios buvo sodinamos i specialią kẻdę prie stalo (nugara tiesi ir atremta i kèdès atlošą, abi rankos sulenktos per alkūnès sąnari $90^{\circ}$ kampu taip, kad žastai priglustu prie šonų, dilbiai remtųsi i i̇renginio atraminę plokštę; kojos sulenktos $90^{\circ}$ kampu per kelius ir pėdomis remiasi i grindis). Irenginio kèdès padètis buvo reguliuojama taip, kad tiriamosios galètų atsisèsti patogiai, užimdamos standartinę padètį. Psichomotorinès reakcijos laikas (RL) buvo matuojamas reakciometru (RA-1, „Baltec CNC Technologies”, Lietuva), skirtu psichomotorinès reakcijos greičiui ir centrinès nervu sistemos funkcinei būklei vertinti. Eksperimento metu prieš krūvi ir po jo buvo registruojamas psichomotorinès reakcijos laikas nuo vienos spalvos lemputès užsidegimo momento iki atitinkamo klavišo paspaudimo (jei užsidega žalia, yra spaudžiamas dešinysis klavišas dešine ranka, jei raudona - kairysis kaire ranka). Psichomotorinès reikacijos laikas buvo matuojamas milisekundèmis (ms). Visi duomenys perduodami ir apdorojami kompiuteriu. Tiriamosios atliko 15 bandymų abiem rankom.

Tyrimo organizavimas. Savaitę prieš eksperimentą kiekviena tiriamoji atskirai buvo mokoma atlikti psichomotorinès reakcijos laiko testą. Tiriamosios buvo mokomos vieną kartą atlikti po 15 bandymu abiem rankom. Su kiekviena tiriamaja buvo atlikti 2 eksperimentai: folikulinèje fazejje ir ovuliacijos metu. Eksperimentu dienos parinktos atsižvelgiant i tiriamosios mènesinių ciklo trukmę ir ovuliacijos diena. Kiekviena tiriamoji 3 mènesius prieš eksperimenta matavo rektalinę temperatūrą - šitaip buvo nustatoma ménesiniu ciklo trukmé, ovuliacijos diena. Tyrejjas pagal kiekvienos tiriamosios rektalinę temperatūrą ir mènesinių ciklo trukmę kiekvienai tiriamajai atskirai paskirdavo eksperimento dieną. Visu eksperimentu pradžioje - prieš psichomotorinès reakcijos testą - paimamas kraujo méginys menstruacinio 
ciklo fazèms (folikulinei, ovuliacinei) nustatyti. Eksperimentas buvo vykdomas 2 dieną nuo menstruacinio ciklo pradžios (folikulinès fazès) ir 14 dieną nuo menstruacinio ciklo pradžios (ovuliacijos) (Hellstrom, Lundberg, 2000; Vaičeliūnienè ir kt., 2006).

Paèmus kraujo mėgini ir atlikus psichomotorinès reakcijos testą, tiriamosios po $10-15 \mathrm{~min}$ neintensyvios pramankštos (lèto važiavimo velorgometru, kai pulso dažnis $120-130 \mathrm{k}$. / min) ant kontaktinès platformos nuo $75 \mathrm{~cm}$ aukščio pakylos atliko 100 šuolių, amortizuojamai pritūpdamos per kelių sąnarius iki $90^{\circ}$ kampo (rankos ant juosmens). 100 šuoliu truko apie 35 min (laiko intervalas tarp visų šuolių -20 sekundžių) (Skurvydas et al., 2006). Praejus 1 min po fizinio krūvio, tiriamujų buvo prašoma dar kartą atlikti psichomotorinès reakcijos testa.

Matematinè statistika. Tyrimo duomenu analizė atlikta naudojant Excel ${ }^{\circledR} 2003$ programą. Vertindami gautus duomenis, skaičiavome aritmetini vidurkị, standartini kvadratinį nuokrypi.
Analizuojamų rodikliu kaitos priklausomumas nuo estradiolio koncentracijos kraujyje ir menstruacinio ciklo fazių, nuo psichomotorinès reakcijos laiko ir menstruacinio ciklo fazių buvo nustatomas naudojant SPSS programu paketa. Estradiolio koncentracijos kraujyje menstruacinio ciklo metu ir psichomotorinès reakcijos laiko sąsajoms nustatyti buvo taikytas Pirsono tiesinès koreliacijos metodas. Patikimumo lygmuo pasirinktas $\mathrm{p}<0,05$.

\section{REZULTATAI}

Lyginant estradiolio koncentracijos kraujyje reikšmes folikulinèje fazejje ir ovuliacijos metu, pastebimas patikimas reikšmiu skirtumas $(\mathrm{p}<0,05)(1$ pav.). Estradiolio koncentracija kraujyje ovuliacijos metu buvo didesnè $(214,43 \pm 81,1)$ nei folikulinèje fazejje $(138,65 \pm 50,2)$ (1 pav.).

Dviejų veiksnių dispersinè analizè rodo, kad lyginant dešinès rankos paprastosios reakcijos laiką prieš krūvị folikulinejje fazèje ir ovulia-
1 pav. Estradiolio koncentracija kraujyje folikulinejje fazèje ir ovuliacijos metu

Pastaba. * - estradiolio koncentracijos kraujyje pokytis, lyginant rodiklius folikulinejje fazèje ir ovuliacijos metu $(\mathrm{p}<0,05)$.

2 pav. Dešinès rankos reakcijos laikas prieš krūvị ir po jo
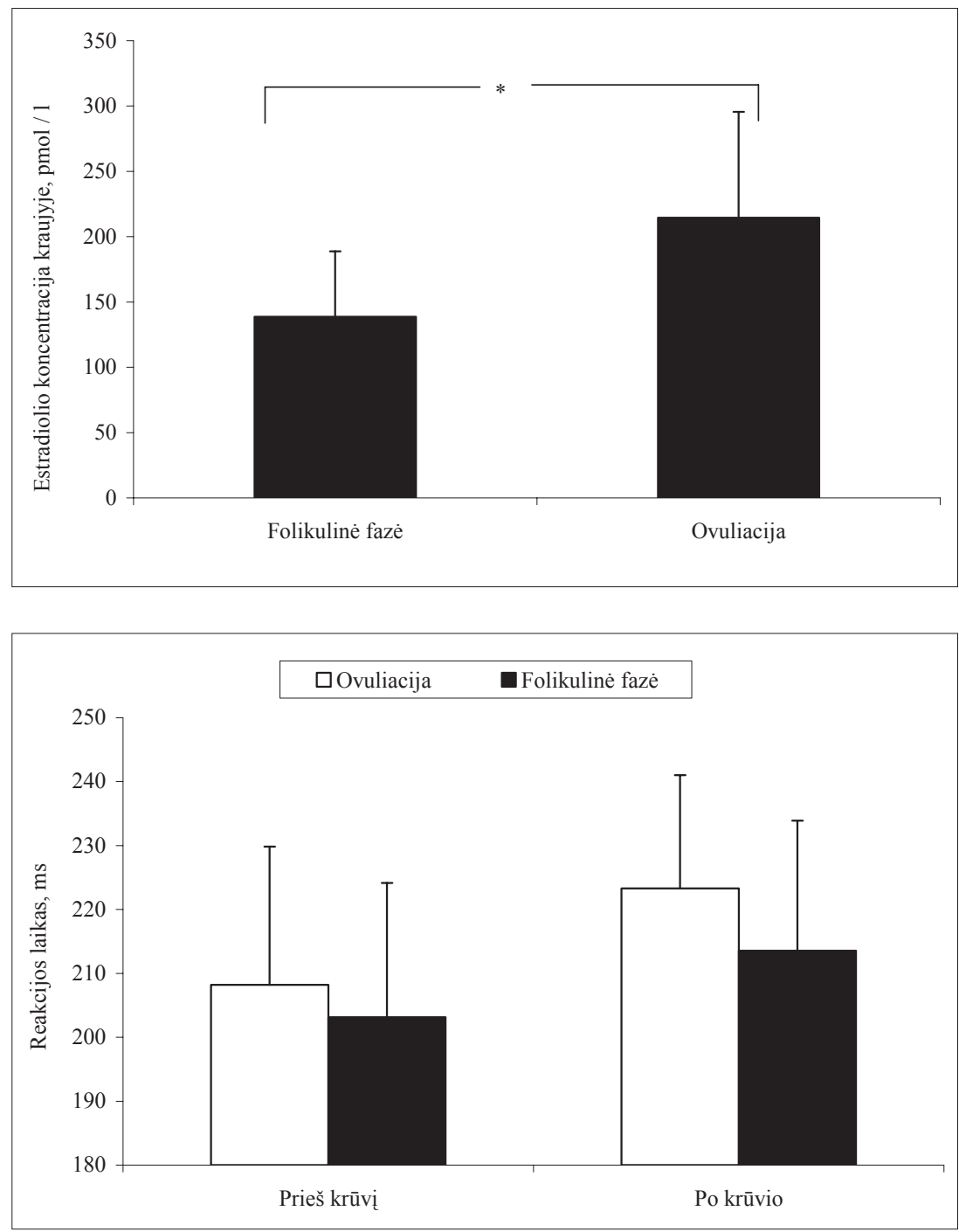


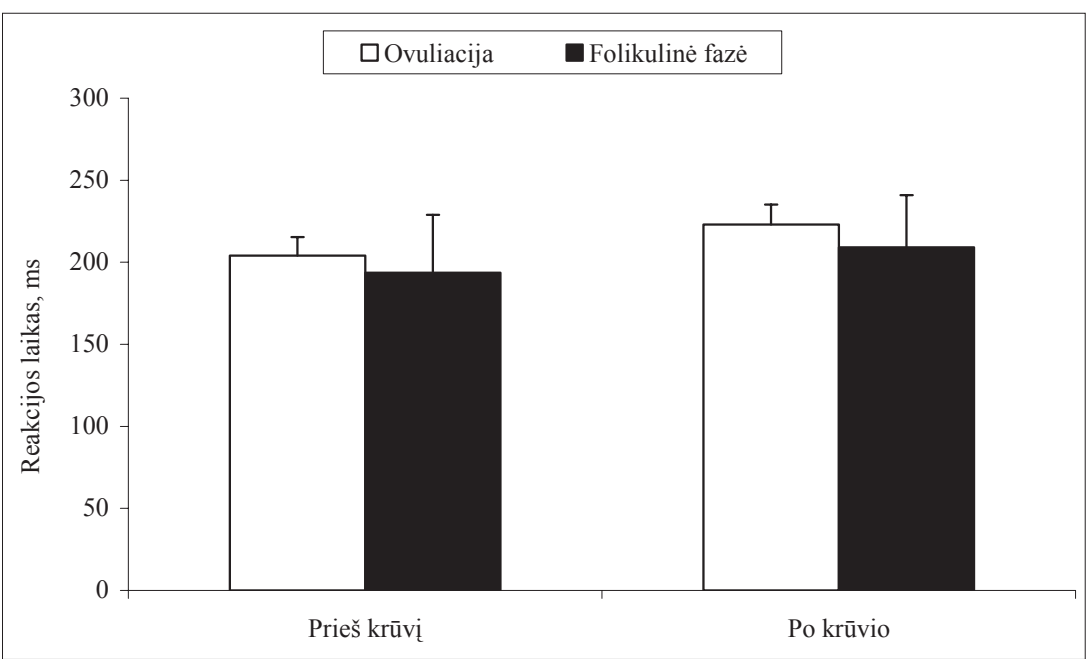

3 pav. Kairès rankos reakcijos laikas prieš krūvị ir po jo

cijos metu nèra patikimo skirtumo $(\mathrm{p}>0,05)$ (2 pav.), taip pat patikimo skirtumo neaptikta, lyginant dešinès rankos paprastosios reakcijos laiką po krūvio folikulinejje fazejje ir ovuliacijos metu (p > 0,05) (2 pav.). Atlikus dvieju veiksniu dispersinę analizę nustatyta, kad lyginant dešinès rankos paprastosios reakcijos laiką prieš krūvi folikulinèje fazejje ir po jo patikimo skirtumo nèra $(\mathrm{p}>0,05)$ (2 pav.), neaptikta patikimo skirtumo ir lyginant dešinès rankos paprastosios reakcijos laiką prieš krūvị ovuliacijos metu ir po jo (p > 0,05) (2 pav.).

Atlikus dviejų veiksnių dispersinę analizę nustatyta: lyginant kairès rankos paprastosios reakcijos laiką prieš krūvị folikulinèje fazejje ir ovuliacijos metu, patikimo skirtumo neaptikta $(\mathrm{p}>0,05)$ ( 3 pav.), taip pat nèra patikimo skirtumo, lyginant dešinès rankos paprastosios reakcijos laiką po krūvio folikulinèje fazèje ir ovuliacijos metu $(p>0,05)(3$ pav.). Lyginant kairès rankos paprastosios reakcijos laiką prieš krūvị folikulinèje fazèje ir po jo, patikimo skirtumo nèra, patikimo skirtumo nenustatyta ir lyginant kairès rankos paprastosios reakcijos laiką prieš krūvị ovuliacijos metu ir po jo $(p>0,05)$ (3 pav.).

Atlikus koreliacinès analizès skaičiavimus nustatyta, kad yra silpnas atvirkštinis koreliacinis ryšys tarp estradiolio koncentracijos kraujyje rodiklių folikulinèje fazèje ir kairès rankos po krūvio, dešinès rankos paprastosios reakcijos laiko (RL) prieš krūvį ir po jo. Silpnas koreliacinis ryšys tarp estradiolio koncentracijos kraujyje rodiklių folikulinèje fazeje ir kairès rankos paprastosios reakcijos laiko (RL) prieš krūvị, tarp jų nèra ir patikimo skirtumo $(p>0,05)$. Silpnas atvirkštinis koreliacinis ryšys nustatytas tarp estradiolio koncentracijos kraujyje ovuliacijos metu ir dešinès, kairès rankos paprastosios reakcijos laiko (RL) prieš krūvị ir po jo, taip pat nèra patikimo šių rodikliu skirtumo $(\mathrm{p}>0,05)$ (žr. lent.).

\section{REZULTATU APTARIMAS}

Didžiausia estradiolio koncentracija kraujyje yra 14 dieną nuo menstruacinio ciklo pradžios, jei menstruacinis ciklas yra reguliarus (McEwan, Alves, 1999; Hellstrom, Lundberg, 2000; Vaičeliūnienè ir kt., 2006). M. Hoffman ir kt. (2008) teigia, kad tirtu 28 moterų, kurių amžius - 22 metai, didžiausia estrogeno koncentracija kraujyje yra 11 dieną nuo menstruacinio ciklo pradžios. Mūsų tyrimo metu estradiolio koncentracija kraujyje nustatyta 2 ir 14 dieną nuo menstruacinio ciklo pradžios. Kaip tik 2-4 dieną (priklausomai nuo savijautos) yra skiriama folikulinè moters lytinio ciklo fazè, 14 dieną nuo menstruacinio ciklo pradžios — ovuliacija (McEwen, Alves, 1999; Hellstrom, Lundberg, 2000; Vaičeliūnienė ir kt., 2006). Mums buvo svarbios 2 moters lytinio ciklo fazès: folikulinė ir ovuliacijos. Tyrimo metu folikulinejje fazejje estradiolio koncentracija kraujyje buvo $138,65 \pm 50,2 \mathrm{pmol} / 1$, ovuliacijos metu $214,43 \pm 81,1 \mathrm{pmol} / 1$. Taigi duomenys patvirtino nuomonę, kad estradiolio koncentracija kraujyje per moters lytinį ciklą yra didžiausia ovuliacijos metu.

\begin{tabular}{|l|c|c|c|c|}
\hline $\begin{array}{c}\text { Estrogeno koncentracija } \\
\text { kraujyje }\end{array}$ & $\begin{array}{c}\text { Dešinės rankos } \\
\text { RL prieš krūvi }\end{array}$ & $\begin{array}{c}\text { Kairès rankos } \\
\text { RL prieš krūvị }\end{array}$ & $\begin{array}{c}\text { Dešinės rankos } \\
\text { RL po krūvio }\end{array}$ & $\begin{array}{c}\text { Kairès rankos } \\
\text { RL po krūvio }\end{array}$ \\
\hline Folikulinė faze் & $-0,22$ & 0,16 & $-0,48$ & $-0,17$ \\
\hline Ovuliacija & $-0,11$ & $-0,14$ & $-0,41$ & $-0,25$ \\
\hline
\end{tabular}

Lentelè. Estradiolio koncentracijos kraujyje folikulinėje fazèje, ovuliacijos metu bei dešinès ir kairès rankos reakcijos laiko ( $R L)$ prieš krūvị ir po jo rodiklių koreliacijos koeficientas 
Estrogeno poveikis neuronų aktyvumui žinomas seniai. Visgi daugelis mokslininkų teigia, kad estrogeno sintezę veikia tik galvos smegenys (McEwen, 2002). Tačiau estrogeno receptoriai yra tiek galvos, tiek nugaros smegenyse, kurios atlieka slopinimo ir aktyvinimo funkcijas. P. J. Shughrue ir kt. (1997) nustaté specifinę abiejų estrogeno receptoriu ( $\alpha$ ir $\beta$ ) lokolizaciją žiurkiu centrinèje nervų sistemoje. Jie teigia, kad 1 tipo, o dažniausiai abiejų, estrogeno receptoriai buvo rasti žiurkių nugaros smegenyse. Todèl informacija, susijusi su estrogeno receptoriais nugaros smegenyse, veikia nervo ir raumens sinapsès monosinapsini ciklą. Estrogeno receptoriai yra nugaros smegenyse tarp sinapsès alfa Ia aferentų ir motoneuronų, todèl estrogeno koncentracijos kraujyje kaita gali lemti alfa aferentinių motoneuoronu aktyvumą, o sinapsinio signalo metu estrogenas sąveikauja su neurotransmiteriu acetilcholinu (Hoffman et al., 2008). Mūsų tyrimo metu tirta paprastoji reakcija, kai tiriamosios kaip imanoma greičiau turejo sureaguoti į užsidegusią lemputę. Reakcijos trukmė susideda iš kelių žingsnių — dirgiklio apdorojimo, sprendimo sudarymo ir konkretaus nervinio mechanizmo suformavimo judesio programai atlikti (Skurvydas et al., 2009). Taigi iš regos analizatoriaus dirgiklis sklinda į smegenų pusrutulių asociacinę sriti, vèliau neuronais ši informacija pereina per pagumburi, nugaros smegenimis - $-i$ periferiją, tada motoneuronai su raumeninèmis skaidulomis sudaro nervo ir raumens sinapsini ryši, ir rankų raumenys atlieka motorinę veiklą. Vèliau sensorinis stimulas, kylantis iš periferijos receptoriu, sensoriniais neuronais per nugaros smegenu viršutinius ragus jungiasi su tarpiniais neuronais ir patenka i pagumburį, kur grižtamoji informacija tarpiniais neuronais perduodama i smegenu pusrutulių asociacinę sritị (Tortora, Derickson, 2006). Taigi padidejusi estrogeno koncentracija kraujyje sutrikdo sinapsinio signalo metu neurotransmiterio acetilcholino veiklą, todèl ovuliacijos metu (kai estrogeno koncentracija didžiausia) dèl pablogejusios neuroraumeninès koordinacijos dažnesnès kelio sąnario kryžmeninių raiščių traumos (Wojtys et al., 2002). Darome prielaidą, kad dèl to paties estrogeno koncentracijos kraujyje padidejimo, kai sinapsinio signalo metu sutrikdoma neurotransmiterio acetilcholino veikla, mūsų tirtos paprastosios reakcijos (tiriamosios kiek imanoma greičiau turèjo sureaguoti i užsidegusią lemputę) laikas prieš krūvi ovuliacijos metu ir po jo buvo ilgesnis nei folikulinèje fazèje, kai estrogeno koncentracija kraujyje yra mažesnè.
C. Friden ir kt. (2003), tyrineddami, kaip estrogenas veikia pusiausvyrą ir kinesteziją, teigia, kad estrogenas lemia glutamato receptoriu funkcijas smegenèlèse. Taigi dèl padidejusios estrogeno koncentracijos kraujyje blogiau atliekamas taisyklingas judesys, blogesnè judejjimo koordinacija, pusiausvyra, lyginant šiuos rodiklius folikulinèje ir liuteinineje fazèse. Ovuliacijos metu taip pat nustatytas vizualinis jautrumas, kuris sutrikdo paprastą regos analizatoriaus veiklą (Farage et al., 2008), o paprastosios reakcijos greiti kaip tik lemia regos analizatoriaus komponentai (Sturm et al., 1999), kurie ovuliacijos metu pailgina paprastosios reakcijos laiką. Tai rodo ir atlikto tyrimo duomenys.

Analizuojant dešinès ir kairès rankos psichomotorinès reakcijos laiko rodiklius tiek ovuliacijos metu, tiek folikulinèje fazèje pastebimas trumpesnis dešinès rankos psichomotorinès reakcijos laikas, tačiau patikimo statistinio skirtumo nèra. Tai sutampa su kitu autoriu tyrimo duomenimis (Yin-Chen Shen, Franz, 2005). Lyginant dešinès ir kairès rankos psichomotorinès reakcijos laiko rodiklius prieš krūvị ir po jo tiek ovuliacijos metu, tiek folikulinèje fazèje, psichomotorinès reakcijos laikas buvo ilgesnis po fizinio krūvio. Tai sutampa su mokslininkų nuomone, teigiančia, kad atsiradus nuovargiui psichomotorinès reakcijos laikas pailgèja (Poderys ir kt., 2006).

Rodiklių vertinimas parodè silpną koreliacini ryši tarp estradiolio koncentracijos kraujyje bei psichomotorinès reakcijos laiko ovuliacijos metu ir folikulinejje fazèje. Vadinasi, psichomotorinès reakcijos laikas nepriklauso nuo estradiolio koncentracijos kraujyje ir ovuliacijos metu, ir folikulinèje fazejje. Visgi nèra aišku, ar psichomotorinès reakcijos laikas priklauso nuo estradiolio koncentracijos kraujyje liuteininèje fazeje, kai organizme vyksta visiškai skirtingi neurocheminiai procesai nei ovuliacijos metu ar folikulineje fazèje. Todèl moksliniai tyrimai turètų būti tęsiami norint gauti išsamesnes mokslines išvadas.

\section{IŠVADOS}

1. Reakcija i paprastą dirgikli buvo ilgesnè ovuliacijos metu nei folikulinejje fazejje, tačiau šis skirtumas nebuvo statistiškai reikšmingas.

2. Reakcijos ị paprastą dirgiklị ir estradiolio koncentracijos kraujyje vertinimai rode silpną rodiklių koreliacini ryši tiek ovuliacijos metu, tiek folikulinejje fazejje. 


\title{
LITERATŪRA
}

Farage, M. A., Osborn, T. W., MacLean, A. B. (2008). Cognitive, sensory, and emotional changes associated with the menstrual cycle: A review. Archives of Gynecology and Obstetrics, 278, 299-307.

Friden, C., Hirschberg, A. L., Saartok, T. (2003). Muscle strength and endurance do not significantly vary across 3 phases of the menstrual cycle in moderately active premenopausal women. Clinical Journal of Sport Medicine, $13,238-241$.

Friden, C., Hirschberg, A. L., Saartok, T., Renstrom, P. (2006). Knee joint kinaesthesia and neuromuscular coordination during three phases of the menstrual cycle in moderately active women. Knee Surgery, Sports Traumatology Arthrose, 14, 383-389.

Hellstrom, B., Lundberg, U. (2000). Pain perception to the cold pressor test during the menstrual cycle in relation to estrogen levels and a comparison with men. Integrative Physiological and Behavioral Science, 35, 2, 132-141.

Hoffman, M., Harter, R. A., Hayes, B. T., Wojtys, E. M., Murtaugh, P. (2008). The interrelationships among sex hormone concentrations, motorneuron excitability, and anterior tibial displacement in women and men. Journal of Athletic Training, 43 (4), 364-372.

Maki, P. M, Rich, J. B., Rosenbaum, R. S. (2002). Implicit memory varies across the menstrual cycle: Estrogen effects in young women. Neuropsichologia, 40, 518-529.

McEwen, B. (2002). Estrogen actions throughout the brain. Recent Progress in Hormone Research, 57, 357-384.

McEwen, B. S, Alves, S. E. (1999). Estrogen actions in central nervous system. Endocrine Reviews, 20, 3, $279-280$.

Morofushi, M., Shinohara, K., Kimura, F. (2001). Menstrual and circadian variations in time perception in healthy women and women with menstrual syndrome. Neuroscience Research, 42, 339-340.

Nelson, A. L. (2006). Extended-regimen contraception: effects on menstrual symptoms and quality of life. Journal of Family Practice, 55, S1-8.

Philips, S. M., Sherwin, B. B. (1992). Variations in memory function and sex steroid hormones across the menstrual cycle. Psychoneuroendocrinology, 17, 497-506.
Poderys, J., Venskaitytè, E., Poderytė, K., Ežerskis, M., Buliuolis, A. (2006). Dvikovos sporto šaku atstovu atsigavimo proceso ypatybès ir jų kaita po didelès apimties koncentruotu jègos greitumo krūviu. Sporto mokslas, 1 (43), 48-52.

Shen Yin-Chen, Franz, E. A. (2005). Hemispheric competition in left-handers on bimanual reaction time tasks. Journal of Motor Behavior, 37, 1, 3-9.

Shughrue, P. J., Lane, M. V., Merchenthaler, I. (1997). Comparative distribution of estrogen receptor-alpha and beta mRNA in the rat central nervous system. Journal of Comparative Neurology, 388 (4), 507-525.

Skurvydas, A., Gutnik, B., Zuoza, A. K. et al. (2009). Relationship between simple reaction time and body mass index. HOMO - Journal of Comparative Human Biology, $60,77-85$

Skurvydas, A., Kamandulis, S., Stanislovaitis, A. et al. (2006). Dynamics of indirect symptoms of skeletal muscle damage after stretch-shortening exercise. Journal of Electromyography and Kinesiology, 16 (6), 629-636.

Sturm, W., de Simone, A., Krause, B. J. et al. (1999). Functional anatomy of intrinsic alertness: Evidence for a fronto-parietal-thalamic-brainstem network in the right hemisphere. Neuropsychologia, 37, 797-805.

Tortora, G. J., Derickson, B. (2006). Principles of Anatomy and Physiology. 11th ed. Chichester: John Wiley and Sons Inc.

Vaičeliūnienė, A., Grikšienė, R., Jablonskienè, V., Rukšènas, O. (2006). Ką apie ménesiniu ciklą žino Lietuvos 18 -25 metu merginos? Laboratoriné medicina, 3 (31), $37-40$.

Wojtys, E. M., Ashton-Miller, J. A, Huston, L. J. (2002). A gender-related difference in the contribution of the knee musculature to sagittal-plane shear stiffness in subjects with similar knee laxity. The Journal of Bone and Joint Surgery, 84, A, 10-16.

Wolkowitz, M. O., Rothschild, J. A. (2003). Psychoneuroendocrinology: The Scientific Basis of Clinical Practice. Washington DC: American Psychiatric Publishing Inc. P. $319-320$

\section{DEPENDENCE OF WOMEN'S PSYCHOMOTOR REACTION RATE ON THEIR MENSTRUAL CYCLE PHASE}

\author{
Laura Daniusevičiūtè $\dot{1}^{1,2}$, Albertas Skurvydas ${ }^{1}$, Irina Ramanauskiené ${ }^{2}$, Vitas Linonis ${ }^{2}$, \\ Saulè Sipavičiené ${ }^{1}$, Marius Brazaitis ${ }^{1}$ \\ Lithuanian Academy of Physical Education ${ }^{1}$, Kaunas University of Technology ${ }^{2}$, \\ Kaunas, Lithuania
}

The aim of our study — to establish the dependence on women reaction rate and menstrual cycle: in follicular phase and ovulation.

Subjects - healthy and physically active women $(n=9)$ with normal menstrual cycle whose age was $19-23$ years. Their body weight $-58.2 \pm 6.1 \mathrm{~kg}$, height $-168.4 \pm 5.6 \mathrm{~cm}$. All the participants did not use oral contraceptives during 6 months and had regular menstrual cycles. At the begining of every experiment the sample of $5 \mathrm{ml}$ venum blood was taken to establish the menstrual cycle phases: the follicular phase and 
the ovulation phase. In our study we measured estradiol concentration in blood on the second day of the menstrual cycle (follicular phase) and on the fourteenth day of the menstrual cycle (ovulation). Also, to estimate the duration of the menstrual cyle and the ovulation day, every morning each participant measured the rectal temperature for 3 months before the experiment. Reaction time was estimated by reaction-meter (RA-1, „Baltec CNC Technologies”, Lithuania), which is apllied to estimate the functional state of the central nervous system (CNS), simple and complex reaction time, and the frequency of movements. One week before the experiment the participants were instructed to perform the reaction time test. During the instructions every participant performed 15 tests one time each test using both hands. During the experiment before and after the load we estimated the reaction time of the left and the right hands from the moment the light was on and till the moment when the platform was toutched (ms). The participants performed 15 tests using both hands. We made 2 experiment with each participant s: in the follicular phase and the ovulation phase. The days for the experiments were chosen considering the duration of the menstrual cycle and the ovulation day of each participant. After 10-15 min of not-intensive warming-up (slow pedaling velorgometer, with the heart rate of $120-130 \mathrm{~b} / \mathrm{min}) 100$ jumps on vertical jump force plate from a $75 \mathrm{~cm}$ stage were made, when the participant got to amortization phase while the knee joints were flexed at the angle of $90^{\circ}$ (hands on loins).

The research showed that reaction to simple stimulus was longer in the ovulation phase than in follicular phase, but this difference was not significant. Correlation values of reaction to simple stimulus and estradiol concentration showed a weak correlation in the ovulation and the follicular phases.

Keywords: psychomotor reaction time, follicular phase, ovulation.

Gauta 2009 m. kovo 4 d.

Received on March 4, 2009

Priimta 2009 m. gegužès 6 d.

Accepted on May 6, 2009

\author{
Laura Daniusevičiūtė \\ Lietuvos kūno kultūroa akademija \\ (Lithuanian Academy of Physical Education) \\ Sporto g. 6, LT-44221 Kaunas \\ Lietuva (Lithuania) \\ Tel +37060065490 \\ E-mail lauruka@yahoo.com
}

